\title{
Effect of Breast Care and Oxytocin Massage on Breast Milk Production: A study in Sukoharjo Provincial Hospital
}

\author{
Tutik Rahayuningsih'), Ambar Mudigdo²), Bhisma Murti ${ }^{2,3)}$ \\ ${ }^{1)}$ School of Health Polytechnics, Poltekkes Bhakti Mulia, Surakarta \\ 2)Faculty of Medicine, Universitas Sebelas Maret, Surakarta \\ 3)Masters Program in Public Health, Universitas Sebelas Maret, Surakarta
}

\begin{abstract}
Background: The prevalence of exclusive breast feeding was 39.05\% in Sukoharjo in 2015, which is far bellow the national target of $80 \%$. A study has shown that massage oxytocin increases oxytocin (OT) hormone release, and eventually decreases adrenocorticotropin hormone (ACTH), nitric oxide (NO), and beta-endorphin (BE). This OT hormone release will increase milk ejection, which facilitate milk production. This study aimed to investigate the effect of breast care and oxytocin massages on breast milk production in post-partum mothers.

Subjects and method: This was a Randomized Controlled Trial (RCT), conducted at Sukoharjo Hospital, Central Java 19 October to November 18, 2016. A total of 90 post - partum mothers were selected at random and then allocated into breast care group and oxytocin massage group. The dependent variable was breast milk production. The independent variable was breast care and oxytocin massage. Changes in breast milk production before and after intervention between the two groups were tested by Mann-Whitney test.

Results: The increase in breast milk production in breast care and oxytocin massage group (mea $=17.37, \mathrm{SD}=9.70$ ) was larger than that of the control group (mean=1.58, $\mathrm{SD}=1.69$ ), and it was statistically significant $(\mathrm{p}<0.001)$.

Conclusion: Breast care and oxytocin massage can significantly increase breast milk production. Post-partum mothers are recommended to practice breast care and oxytocin massage, in order to increase breast milk production.
\end{abstract}

Keywords: breast care, oxytocin massage, breast milk production.

Correspondende:

Tutik Rahayuningsih. School of Health Polytechnics, Poltekkes Bhakti Mulia, Surakarta. Email: tutikrahayu_abm@yahoo.co.id.

\section{BACKGROUND}

$\overline{\text { Breast Milk is the milk produced by huma- }}$ ns for infants and is the main source of nutrition for infants who have not been able to digest solid foods. According to Nugroho (2014) breast milk is the first natural food for babies, containing all the energy and nutrients the baby needs in the first month of life. Exclusive breastfeeding is breastfeeding without other supplementary foods in infants aged o-6 months (Nurheti, 2010). Exclusive breastfeeding provides many benefits for the baby, such as for nutrition, increasing endurance, intelligence, and affection with his mother (Roesli, 2013).

Based on survey data from the Indonesian Demographic Health (IDHS) in 2012 on the IMR in Indonesia, there are 32 deaths per 1,00o live births. The number is higher than the infant mortality rate expected in the MDG's by 2015 is 23 per 1,000 live births (Ministry of Health, 2014). IMR in Indonesia in 2012 resulting from lack of breastfeeding in infants aged less than 6 months reaches $54 \%$ in infants aged 2-3 months, $19 \%$ in infants aged 7-9 months, 
Journal of Maternal and Child Health (2016), 1(2): 101-109

https://doi.org/10.26911/thejmch.2016.01.02.05

$13 \%$ of infants under 2 months have been given milk formula and 1 in 3 infants aged 2-3 months have been given additional food (Lactation Center Indonesia, 2012).

One of the factors contributing to this high IMR is the low coverage of exclusive breastfeeding, because without exclusive breastfeeding infants are more susceptible to various diseases that increase morbidity and mortality. Exclusive breastfeeding helps in decreasing IMR by $13 \%$ (Roesli, 2013).

The report data released by the IDHS Institution in 2007 shows the exclusive breastfeeding coverage of infants aged o-6 months by $32 \%$. While the IDHS report in 2012 there is an increase in infants who get exclusive breastfeeding by $42 \%$. This number of survey result is clearly below the WHO target of breastfeeding coverage of at least $50 \%$. The coverage of exclusive breastfeeding in Indonesia is still below the target that is infants aged o- 6 months with coverage rate of $61.5 \%$, while exclusive breastfeeding coverage in 2012 is $33.6 \%$, and in 2013 at $54.3 \%$. Coverage of exclusive ASI in Central Java in 2011 amounted to $45.86 \%$, in 2012 to $25.06 \%$ and in 2013 to $57.67 \%$, that number is still far from the national target for exclusive breastfeeding coverage in 2014 that is $80 \%$.

The coverage of exclusive breastfeeding in Sukoharjo Regency is $54.73 \%$ and the coverage of exclusive breastfeeding in Sukoharjo Hospital has a rate of $39.05 \%$, where the Sukoharjo Regency Health Office targets the infant to receive exclusive breastfeeding by $65 \%$ (Kemenkes 2014, Pangesti et al., 2015).

Based on the interviews with the Head of Maternity Room Sukoharjo Hospital, obtained data of post-natal mothers have not breastfed their babies because of fatigue during labor, do not know the function of breastfeeding and baby sucking that cause mothers be lazy and delay to breastfeed their babies. From the initial assessment, there got 10 post-partum mothers. On the first day, the breast milk from 6 of the study subjects (6o\%) had not come out. The mothers complained that they had a low milk supply, and worried that the baby was not breastfed so they chose to give milk formula.

The fact in the hospital shows the low production and ejection of breast milk in the post-partum mother on the first day after giving birth become obstacles in early breastfeeding. A study by Nilamsari et al. (2014) showed that $60 \%$ of 47 post-partum women have low breast milk supply on the first day until the third day after delivery. A study by Isnaini (2015) showed that of 78 post-partum women, there are 44 (56.4\%) of them who complain about no breast milk on the first day post-partum, and 13 (16.6\%) post-partum mothers complain about their low breast milk supply and 21 (27\%) post-partum complain of breast milk are not coming out smoothly causes mothers to choose formula milk. According to Cox (2006) mothers who do not breastfeed their babies in the first days were caused by anxiety and mother's fear of low breast milk production and lack of mother's knowledge of the breastfeeding process. Twenty-four hours after delivery is a very important moment for the success of further breastfeeding.

The inadequacy of breast milk production is the main reason for a mother to stop breastfeeding early. The mother feels she does not have enough breast milk to meet the baby's needs and support the baby's weight gain. Effective treatments to increase milk production include breastcare by maintaining breast health and breast massage, breast exercise and oxytocin massage. 
Breast care aims to smooth blood circulation and prevent blockage of milk production channels so as to facilitate the milk flow during breastfeeding. Oxytocin massage is a massage on the part along the spine to the $5^{\text {th }}$ and 6 th rib bones which is an attempt to stimulate the hormone prolactin and oxytocin after delivery and can calm the mother, so that breast milk can come out (Widiyanti, 2014).

The purpose of this study was to analyze the effect of breast care and oxytocin massage on breast milk production in post-partum mothers in Sukoharjo Hospital, East Java.

Table 1. Characteristics of study subjects

\begin{tabular}{|c|c|c|c|c|c|c|}
\hline Variable & $\mathbf{n}$ & Mean & Median & SD & Min. & Max. \\
\hline Age of mother (yrs) & 90 & 28.38 & 28.00 & 5.515 & 18 & 42 \\
\hline $\begin{array}{l}\text { Breast milk production before } \\
\text { treatment (cc) }\end{array}$ & 90 & 1.22 & 0.00 & 1.970 & o & 10 \\
\hline $\begin{array}{l}\text { Breast milk production after treatment } \\
\text { (cc) }\end{array}$ & 90 & 8.13 & 3.00 & 10.925 & $\mathrm{o}$ & 50 \\
\hline Difference & 90 & 6.91 & 2.50 & 9.485 & -3 & 40 \\
\hline
\end{tabular}

Based on Table 1,30 study subjects who performed breast care and oxytocin massage and 60 study subjects as control group largely dominated by mothers aged 20-35 years as many as 76 people $(84.4 \%)$ and the lowest group of mothers with age $<20$ years as many 6 people $(6.7 \%)$. Characteristics of data sample categorized the intervention group and the control group and 90 subjects in the intervention group study of 30 people (33.33\%) and the control group was 60 (66.7\%).

\section{Hypothesis Testing}

\section{a. Analisis univariat}

Univariate analysis presented about the influence of breast care and oxytocin massage on the results of pre-production of breast milk produced maximum $10 \mathrm{cc}$

Table 2. Mann Whitney Test Results on changes in breast milk production before and after treatment between intervention and control group

\begin{abstract}
The design of this study was Randomize Controlled Trial (RCT). The study was conducted on October 19 to November 18, 2016 at Sukoharjo Hospital. The study population was post-partum mother. The sampling technique used was simple random sampling, 90 samples of postpartum mothers. Technique of collecting data was done using check list. Data analysis was done using IBM SPSS 22.
\end{abstract}

\section{Characteristics of study subjects}

Characteristics of study subjects are shown in Table 1. while post test results produced milk production maximum $50 \mathrm{cc}$.

\section{b. Normality test}

Normality test result in treatment group and control group obtained result $\mathrm{p}<$ o.oo1) then the data is not normal distribution.

\section{c. Bivariate Analysis}

Bivariate analysis results of breast milk production differences before and after breast and oxytocin massage treatment were shown in Table 2.

n Mean Median

SD

p 
Journal of Maternal and Child Health (2016), 1(2): 101-109

https://doi.org/10.26911/thejmch.2016.01.02.05

Breast care and oxytocin massage
Control
Table 2 showed a statistically significant
difference in breast milk production betw-
een the groups given breast care + oxytocin
massage and the control group. Post-part-
um mothers treated with breast and oxyto-
cin massage produce more breast milk th-
an untreated groups. (Different mean of tr-
eatment $=17.57, \mathrm{SD}=9.70$; difference of
control mean $=1.58, \mathrm{SD}=1.69 ; \mathrm{p}<0.001$ )
The results showed the mean \pm SD of
pre test and post test in the intervention
group was $17.57 \pm 9.70$ and in the control
group was $1.57 \pm 1.69$. It showed that Ho
was rejected and Ha was accepted, meani-
ng there was positive influence of breast
care and oxytocin massage to breast milk
production.

\section{DISCUSSION}

Exclusive breast milk is the natural first, main and the best food for the babies. The benefit of breast milk is so great because it can reduce the risk of infants affected by the disease. In addition, breastfeeding helps the growth and development of children's intelligence. Not all post-partum mothers secrete breast milk because there is a very complex interaction between mechanical stimulation, nerves, and various hormones that affect the expenditure of oxytocin to help produce milk (Prasetyono, 2009).

It is therefore necessary to remove breast milk in the post-partum mothers. In this case there are two processes namely production and expenditure. Breast milk production is affected by the hormone prolactin while expenditure is affected by the hormone oxytocin. The hormone oxytocin will come out with stimulation of the nipples through the baby's mouth sucking or through the massage on the mother's spine. The purpose of the mother's oxy-

\begin{tabular}{lcccc}
30 & 17.57 & 15.00 & 9.70 & $<0.001$ \\
60 & 1.58 & 1.00 & 1.69 & \\
\hline
\end{tabular}

tocin massage will be to feel calm, relax, increase the pain threshold and love the baby, thus stimulating the release of the oxytocin hormone and accelerate the expenditure of breast milk (Endah, 2011).

This study carried out a simultaneous action of breast and oxytocin massage. Breast care was a massage of the breast by giving stimulation of the lactiferous ducts, while the oxytocin massage was doing massage along the spine to the $5^{\text {th }}$ and 6 th rib bones in the mother's body. The purpose of this combination action stimulated the expulsion of the hormone oxytocin to produce milk. Interventions were conducted based on the Standard Operational Procedure (SOP) given to post-partum mothers.

According Sulistyawati (2009) the combination of these two methods resulted in increased milk production through stimulation of touch on the breast and the mother's back that would stimulate the production of oxytocin resulting in contraction of myoepithelial cells.

The postpartum mother feels the pain of labor and causes the mother to be lazy to breastfeed her baby so as to delay breastfeeding in the first days of birth. Delays in the breastfeeding process cause the baby to have nutritional deficiencies, the emotional relationship with the mother is disturbed and the contraction of the myoepithel contractions decreases. If the breastfeeding process is delayed, an alternative action is taken by providing breast care to increase milk production.

The results explained that effective breast care was done to express breast milk. Another study from Maria (2012) said that the habit of breast care in breastfeeding mothers can facilitate milk production by 36 times greater than breastfeeding 
mothers who do not perform breast care. Movement on breast care with massage techniques is recommended with the hands and fingers because it is more practical, effective, efficient and has the advantage of a better pressure that is useful to stimulate the reflex of breast milk expenditure and it is also an effective way to increase the volume of breast milk.

Breast care is a special treatment effort through the provision of stimulation of the breast muscles of the mother by giving body massage. This activity is better done in the morning and evening before bathing and is expected to provide stimulation to the mother's milk glands in order to produce milk (Wulandari, 2011). Physiologically, breast care is done by stimulating the breast to affect the posterior hypofise to release more hormone oxytocin through massage. Oxytocin expenditure is also affected by infant sucking by a receptor in the ductal system. When the ducts are stimulated by massage, the ducts will become wide or softened by releasing oxytocin by hypofise that plays a role to squeeze Mother's Milk from the alveoli (Saleha, 2009). In the first days of the baby's birth, if suction is adequate enough, it will be generated gradually $10-100 \mathrm{ml}$ of milk.

The oxytocin massage is a spinal massage on the back area from the rib cage to 5-6 extending both sides of the spine to the scapula that will speed up the work of the parasympathetic nerves, the nerves that originate on the medulla oblongata and on the sacrum region of spinal cord, stimulates the posterior hipofise to release oxytocin, oxytocin stimulates the contraction of smooth muscle cells that circle the lactific ducts of the mammary gland causing breast myoepithel contractility so as to enhance breastmilk emissions from the mammary glands (Departement of Health, 2007).

This study was conducted on postpartum mother with regard to the time of execution, since the mother gave birth and performed one day in the morning and afternoon. Intervention was done on the first day until the third day post-partum. The amount of breastmilk production prior to breast treatment and the oxytocin massage was excluded by milking by hand and measured using a measuring cup in $\mathrm{ml}$. The results obtained by the maximum volume of breast milk before the breast treatment and massage of oxytocin was 10 ml. Judging from the volume was still somewhat small, this occurs because the mother's efforts to breastfeed in overcoming the problem of breastfeeding was not optimal and breastfeeding mothers who made the subject of study have not known and have never done breast care and massage oxytocin.

Based on the Mann Whitney test the mean \pm SD pre test and post test in the intervention group was $17.57 \pm 9.70$ and in the control group was $1.57 \pm 1.69$. This study showed that breast implants and oxytocin massage may increase breast milk production, increased breastfeeding production received breast treatment and oxytocin massage $($ mean $=17.37 ; \mathrm{SD}=9.70)>$ untreated mothers (mean $=1.58, \mathrm{SD}=$ 1.69), and the difference was statistically significant $(\mathrm{p}<0.001)$.

It showed that Ho was rejected and Ha was accepted meaning there was positive influence of breast care and oxytocin massage to milk production of mother's milk. It is seen that there was a significant difference in the production of breast milk before and after a combination of breast care and oxytocin massage methods in the post-partum mother. Increased milk production could be seen from the volume of 
Journal of Maternal and Child Health (2016), 1(2): 101-109

https://doi.org/10.26911/thejmch.2016.01.02.05

breast milk before the intervention of breast care and oxytocin massage from $\mathrm{O}^{-}$ $10 \mathrm{ml}$ to $10-50 \mathrm{ml}$ after a combination of two massages.

Breast milk production refers to the volume of breast milk released by the breast. Interventions of both breast care and oxytocin massage methods, in principle, aimed to make the myocardial muscles contract, relax the mind and facilitate the expenditure of breast milk. Breast milk expenditure occurs because smooth muscle cells around the breast gland shrink so that squeeze milk to come out. Breast milk could come out of the breast due to the shrinking muscles that could be stimulated by a hormone called oxytocin. Through stimulation of breast massage or stimulation of the spine would relax the tension and relieve stress, assisted by the baby's suction on the nipple as soon as the baby was born with a normal baby's condition, the neurotransmitter would stimulate the medulla oblongata and then sent a message to the hypothalamus in the posterior hypofise to release oxytocin causing breasts removed milk.

The volume of breastmilk produced and released by the breast glands may differ by influencing factors such as the food the mother consumes, the peace of mind and soul, the use of contraceptives, breast care, breast anatomy, physiological factors, resting patterns, child sucking factors or the frequency of breastfeeding, born baby, age of pregnancy during childbirth, and consumption of cigarettes and alcohol (Astutik, 2014). Sulistyawati (2009) argued that the release of oxytocin may be inhibited by the emotional state of the mother, fear, fatigue, shame, uncertainty, or pain.

The results of this study as conducted by Nurhanifah (2013) there is a difference in the smoothness of breast milk production before and after the back massage (oxytocin) and warm breast compresses. The conclusion is that back massage is more effective in the production of breast milk than warm breast compresses. Study conducted by Isnaini (2015) said that there is a relationship between oxytocin massage on postpartum mothers with breastfeeding expenditure. The relationship of breast care and oxytocin massage to breast milk production can increase the production of breast milk significantly through stimulation of massage on the breast muscles directly causing contraction of mioephitel cells and causes the milk to go out smoothly when the baby is feeding on her mother.

Another study by Mardyaningsih (2010), on the effectiveness of combinations of marmetted and oxytocin massage techniques on breastmilk production in post-cesarean mothers, the results of a combination of Marmet techniques and oxytocin massage have an effect on increasing milk production. The conclusion of breast milk production study is strongly influenced by the hormone prolactin that will produce milk, and the hormone oxytocin effect on the smooth expenditure of breast milk, because the more milk out, milk production will increase, so in the above study can be concluded combination of marmet technique and massage oxytocin can stimulate prolactin hormone and oxytocin.

The success of the mother in breastfeeding is influenced by factors after delivery. Breast milk production may increase or decrease depending on stimulation of the breast especially in the first week of breastfeeding. This study conducts two concurrent interventions namely breast care and oxytocin massage and obtains results significantly increase milk 
production. Previous studies have used two different methods and only one of them has been effective in increasing breast milk production, so this study combines the two methods of previous study whose results have effectively increased milk production.

\section{REFERENCES}

Ambarwati ER, Wulandari D (2010). Asuhan kebidanan nifas. Jogjakarta: Nuha Medika.

Anggraini Y (2010). Asuhan kebidanan masa nifas. Yogyakarta: Pustaka Rihama.

Asmuji, Diyan I (2016). Model family centered maternity care sebagai strategi optimalisasi competent mothering. Jurnal Ners. 10 (1) April 2016. Faculty of Health Sciences Muhammadiyah University Jember.

Astutik RY (2014). Payudara dan laktasi. Jakarta: Salemba Medika.

Azwar (2008). Pengantar kuliah obstetri. Jakarta: EGC.

Bahiyatun (2009). Buku ajar kebidanan asuhan nifas normal. Jakarta: EGC.

Bobak IM, Lowdermilk. Jensen MD (2012). Buku ajar keperawatan maternitas. Ed. 4. Jakarta: EGC.

Cox S (2006). Breastfeeding with confidence: panduan untuk belajar menyusui dengan percaya diri. Jakarta: Gramedia.

Dahlan S (2012). Statistik untuk kedokteran dan kesehatan (deskriptif, biva riat, dan multivariat) dilengkapi aplikasi dengan menggunakan SPSS. Jakarta: Salemba Medika.

Depkes RI (2007). Manajemen laktasi. Jakarta: EGC.

Dewi VNL, Tri S (2011). Asuhan kebidanan pada ibu nifas. Jakarta: Salemba Medika.

Endah SN, Masdinarsah I (2011). Pengaruh pijat oksitosin terhadap penge- luaran kolostrum pada ibu post partum di ruang kebidanan rumah sakit muhammadiyah Bandung. Jurnal kesehatan kartika.

Hidayat AA (2008). Metode penelitian keperawatan dan teknik analisis data. Jakarta: Salemba Medika.

Isnaini N, Rama D (2015). Hubungan pijat oksitosin pada ibu nifas terhadap pengeluaran asi di wilayah kerja puskesmas raja basa indah bandar lampung tahun 2015. Jurnal kebidanan 1 (2). Juli 2015.

Jellife DB, Jellife EFP (2006). Community nutritional assesment with special reference to less tehnocallo develop countries. Oxford Medical Publication. Oxford. New York. Tokyo.

Kemenkes (2014a). Kondisi pencapaian program kesehatan anak Indonesia. Jakarta: Kemenkes RI.

Kemenkes (2014b). Situasi dan analisis ASI eksklusif. Jakarta: Kemenkes RI.

Latifah J, Abdurahman W, Agianto (2015). Perbandingan breast care dan pijat oksitosin terhadap produksi asi pada ibu post partum normal. DK Universitas Lambung Mangkurat. 3(1).

Mardiyaningsih E (2010). Efektifitas kombinasi teknik marmet dan pijat oksitosin dapat meningkatkan produksi ASI. Fakultas Ilmu Keperawatan Program Magister Ilmu Keperawatan Kekhususan Keperawatan Maternitas. Jakarta: Universitas Indonesia.

Maria LA, Masni. Burhanuddin B (2012). Faktor determinan kelangsungan pro duksi asi di rumah sakit umum daerah $\mathrm{dr} \mathrm{m}$ haulussy ambon. http://pasca.unhas.ac.id/jurnal/files/57b47a5800888bc5419f5609ac 17ac4e.pdf.

Maryunani A (2009). Asuhan pada ibu dalam masa nifas (postpartum). Jakarta: Trans Info Media. 
Journal of Maternal and Child Health (2016), 1(2): 101-109

https://doi.org/10.26911/thejmch.2016.01.02.05

Muliani RH (2014). Perbedaan produksi asi sebelum dan sesudah dilakukan kombinasi metode massase depan (breast care) dan massase belakang (pijat oksitosin) pada ibu menyusui o-3 bulan di wilayah kerja puskesmas kesamiran kabupaten tegal.

Nilamsari MA, Wagiyo, Elisa (2014). Pengaruh perawatan payudara terhadap kelancaran ekskresi asi pada ibu post partum di rumah bersalin mardi rahayu semarang. Jurnal ilmu keperawatan dan kebidanan (JIKK).

Nugroho T, Nurrezki, Desi W, Wilis (2014). Buku ajar asuhan kebidanan nifas (askeb 3). Yogyakarta: Nuha Medika.

Nurhanifah F (2013). Perbedaan efektifitas massage punggung dan kompres hangat payudara terhadap peningkatan kelancaran produksi asi di desa majang tengah wilayah kerja puskesmas pamotan dampit malang. Rsud Merauke. Jurnal keperawatan, 4 (2).

Nurheti, Yuliarti (2010). Keajaiban asimakanan terbaik untuk kesehatan, kecerdasan, dan kelincahan si kecil. Yogyakarta: C.V Andi.

Pangesti DK, Sulastri, Kartinah (2015). Gambaran pemberian air susu ibu pada ibu dengan bayi usia 6-12 bulan di kesa kadilangu kecamatan baki kabupaten sukoharjo. Fakultas ilmu Keperawatan Universitas Muhammadiyah Surakarta.

Patel U (2013). Effect of back massage on lactation among postnatal mothers. International journal of medical research and Review.

Polit DF, Beck CT (2006). Essentials of nursing research: methods, appraisal, and utilization (6th ed). Philadelphia: Lippincot Williams \& Walkims.
Prasetyono DS (2009). Buku pintar asi eksklusif. Yogyakarta: Diva Press.

Rahayu D, Budi S, Esty Y (2015). Produksi asi ibu dengan intervensi acupresure point for lactation dan pijat oksitosin. FK Universitas Airlangga Surabaya. Jurnal ners. 10 (1).

Roesli U (2013). Mengenal asi eksklusif. Jakarta: Trubus Agriwidya.

Safitri, Wahyu N, Susilaningsih, Ardi P (2015). Pijat punggung dan percepatan pengeluaran asi pada ibu post partum. Poltekkes Kemenkes Malang. Jurnal informasi kesehatan indonesia (JIKI), 1 (2): 148-153.

Saleha S (2009). Asuhan kebidanan pada masa nifas.Jakarta: Salemba Medika.

Sarwinanti (2014). Terapi pijat oksitosin meningkatkan produksi asi pada ibu post partum. Jurnal kebidanan dan keperawatan. 10 (1): 47-53.

Sastroasmoro (2007). Membina tumbuh kembang anak. Jakarta: IDAI.

Setiawan AS (2011). Metodologi penelitian kebidanan DIII, DIV, S1 dan S2. Yogyakarta: Nuha Medika.

Siregar S (2010). Statistik deskriptif untuk penelitian. Jakarta: Rajawali Press.

Sugiyono (2011). Statistik untuk penelitian. Bandung : Alfabeta

Suherni (2010). Perawatan masa nifas. Yogyakarta: Fitramaya.

Sulaeman (2015). The effect of oxytocin massageon the postpartum mother on breastmilk production in surakarta indonesia. International Conference on Health and Well-Being (ICHWB) 2016. Faculty of Medicine, Universitas Sebelas Maret.

Sulistyawati A (2009). Buku ajar asuhan kebidanan pada ibu nifas. Ed. 1. Yogyakarta: Andi.

Widiasih R (2008). Masalah-masalah dalam menyusui. Seminar manaje- 
men laktasi. Bandung Fakultas Ilmu Keperawatan Universitas Padjajaran. Widiyanti AF, Heni S, Kartika S, Rini S (2014). Perbedaan antara dilakukan pijatan oksitosin dan tidak dilakukan pijatan oksitosin terhadap produksi asi pada ibu nifas di wilayah kerja puskesmas ambarawa. Akbid Ngudi Waluyo Ungaran.

Wulandari FT, Fidyah A, Utami D (2014). Pengaruh pijat oksitosin terhadap pengeluaran kolostrum pada ibu post partum di Rsud provinsi kepulauan riau. Poltekkes Kemenkes Tanjung pinang. Jurnal Kesehatan, 5(2).

Wulandari SR, Sri H (2011). Asuhan kebidanan ibu masa nifas. Yogyakarta: Gosyen Publishing. 